\title{
Psychoanalytical Investigation of Clinical Phenomena in Psychosis, in the Pandemic Context of COVID-19
}

\author{
Claudia Henschel de Lima ${ }^{1,2}$ \\ ${ }^{1}$ Psychology Department, Universidade Federal Fluminense, Volta Redonda, Rio de Janeiro, Brazil \\ ${ }^{2}$ Psychology Graduate Program, Universidade Federal do Rio de Janeiro, Rio de Janeiro, Brazil \\ Email: claudialima@id.uff.br
}

How to cite this paper: de Lima, C. H. (2020). Psychoanalytical Investigation of Clinical Phenomena in Psychosis, in the Pandemic Context of COVID-19. Psychology, 11, 1837-1853.

https://doi.org/10.4236/psych.2020.1112116

Received: September 9, 2020

Accepted: December 14, 2020

Published: December 17, 2020

Copyright $\odot 2020$ by author(s) and Scientific Research Publishing Inc. This work is licensed under the Creative Commons Attribution International License (CC BY 4.0).

http://creativecommons.org/licenses/by/4.0/ (c) (i) Open Access

\begin{abstract}
Recent international studies on the impact of the COVID-19 pandemic on mental health motivated the writing of this article. The article presents the preliminary results of the research conducted by me at the Laboratory of Fundamental Psychopathology in Studies on Subjectivity and Humanitarian Emergencies, of the Graduate Program in Psychology at the Federal University of Rio de Janeiro (UFRJ, Brazil). There were five months of theoretical survey of the theme based on the following research problem: what is the impact of social isolation and uncertainty about the future, on the functioning of the self in psychosis? The purpose of the article is to expose the results of the first phase of research on the topic, which consisted of a systematic review of the scientific literature on the topic of humanitarian emergencies, locating pandemics in this classification and specifically asking about the impact of COVID-19 on disorders related to the functioning of the self in psychosis, I finally maintain the relevance of developing a clinical protocol for the psychological approach of these situations, within the framework of the impacts of the COVID-19 pandemic about subjective functioning.
\end{abstract}

\section{Keywords}

COVID-19, Psychosis, Mental Health, Psychopathology

\section{Introduction}

The objective of the article is to present the theoretical survey carried out between March and August 2020 with the research project "Psychoanalytic Investigation of Clinical Phenomena linked to Psychosis, in the Pandemic Context of 
COVID-19", developed in the Graduate Program in Psychology, Federal University of Rio de Janeiro (UFRJ, Brazil).

The high infectious potential and the degree of lethality of COVID-19 (coronavirus disease) is widely known. However, the current stage of scientific knowledge is still moving towards discovering the most accurate drugs for the cure of COVID-19 and developing a vaccine for its prevention. Thus, until now, social isolation and quarantine have been the most accurate methods for preventing COVID-19. The scientific literature has raised the impacts of the pandemic on the population's life routine: difficulty in accessing health services to care for clinical health problems not directly linked to COVID-19, difficulties in accessing means of transportation and maintenance of work routines, unemployment, financial difficulties (Hao, Tan, Jiang, Zhang, Zhao et al., 2020). Such impacts associated with the situation of sudden social isolation and the difficulty of projecting a horizon of normality in the routine of life have also affected mental health to the point of being considered as possible predictors for the occurrence of psychic disorders (Thackur and Jain, 2020). Thus, depression, anxiety, distress, sleep and eating disorders, suicidal ideation, are some well-known examples of the possible effects of a humanitarian emergency of the magnitude of the COVID-19 pandemic on the mental health of populations (Ministério da Saúde, 2020; Lima et al., 2020; Zhang, Wu, Zhao, and Zhang, 2020).

Since 1996, I have investigated the psychic processes at play in triggering psychopathological phenomena such as: use of psychoactive substances, depression, cutting and anorexia. The clinical observation of the dynamics of these phenomena led me to formulate the psychoanalytical hypothesis that the psychic etiology of these psychopathological phenomena is correlated with:

1) The formation of a defense against repressed content, through character. The recognition of this defense provides elements for the formulation of the diagnosis of neurosis underlying the psychopathological phenomena mentioned above.

2) The disturbance in the process of constitution of the self from the unification of the drives, which pressures the psychic functioning to form an imaginary identification. The recognition of this disturbance in the self provides elements for the formulation of the diagnosis of psychosis underlying the psychopathological phenomena mentioned above.

The development of this hypothesis took place in the light of the concepts of repression and foreclosure, making it possible to locate when, for example, food refusal in anorexia or the use of psychoactive substances in chemical dependence, respond to a psychic conflict or when they result directly from the rejection process or foreclosure. The study of clinical cases of patients with these psychopathological phenomena, at the Applied Psychology Service of Federal Fluminense University (UFF, Volta Redonda Campus, Brazil) has allowed to verify the research hypothesis, and to elaborate a model of construction of the clinical case, from the following steps: 
1) Precise delimitation of psychopathological phenomena taking as a criterion the distinction between character and imaginary identification from the collection of the following information from the patient: time of onset, if the outbreak of the phenomenon represented a milestone in the patient's life, delimiting a "before" and an "after", degree of association with psychosocial problems, disease trigger factors or associated life events, types of thinking, affects that the patient finds simultaneous to the onset of the psychopathological phenomenon and how the patient describes these phenomena.

2) Verification of the psychic conditions of constitution of the character or of the imaginary identification, based on the following criteria of recognition of the psychopathological phenomena in the first stage: if it is associated, to some degree, with a psychic conflict covered by the counter-investment that the character ensures against the drive, or cover up features of elementary phenomena.

3) Elaboration of a diagnostic hypothesis of psychosis or neurosis based on the recognition of the psychic process that underlies the presented phenomena: foreclosure or repression.

4) Specific treatment direction and articulated to the diagnostic hypothesis with an initial focus on the stabilization of psychopathological phenomena based on the recognition of the conjuncture in which it occurs in both neurosis and psychosis.

The outbreak of the COVID-19 pandemic in Brazil in March 2020 presented two new variables for the research to be considered in the investigation of these psychopathological phenomena: severe stress on psychic functioning and the weakening of psychic strategies to deal with the humanitarian emergency. That was the reason for me to establish the cooperation between the research of the Laboratory of Fundamental Psychopathology in Studies on Subjectivity and Humanitarian Emergencies, of the Graduate Program in Psychology at the Federal University of Rio de Janeiro (UFRJ, Brazil) and the psychological treatment offered for the project "Virtual Psychological Clinic of the Federal University of Pará: Psychological Care in the COVID-19 Pandemic" of the Graduate Program in Psychology at the Federal University of Pará (UFPA, Brazil). The objective of the cooperation between two graduate programs, signed in March 2020, was to delimit scientific research on the psychic etiology of psychopathological phenomena surrounding psychosis in order to observe whether they are impacted by the pandemic and social isolation measures. The survey carried out from the presentations of the clinical cases attended by the project "Virtual Psychological Clinic of the Federal University of Pará: Psychological Care in the COVID-19 Pandemic" allowed the mapping of some psychopathological phenomena with patients with pre-existing clinical conditions of depression and anxiety:

1) Insomnia.

2) Change in appetite (or overeating or loss of appetite).

3) Fear of being contaminated and of contaminating loved ones.

4) Anxiety. 
5) Intensification of cleansing rituals.

6) Decline in the feeling of life and interest in daily activities.

7) Difficulty in maintaining routine activities.

8) Sadness.

9) Loss of the future horizon.

I compared this mapping with the references provided by the Humanitarian Intervention Guide (GIH-mhGAP): Clinical Management of Mental, Neurological and Substance Use Conditions in Humanitarian Emergencies (PAHO, 2020), verifying the consistency of the mapping done with the assistance of these patients in the state of Belém do Pará (Brazil). But the GIH-mhGAP also reports the worsening of pre-existing psychopathologies: moderate to severe depressive disorder, psychosis and harmful use of alcohol and other drugs. The GIH-mhGAP data reinforce the importance of further researching the psychopathological phenomena of psychosis.

Psychotic patients are more sensitive to environmental changes that directly affect the population's way of life. As they are patients who interpret the world as invasive, the central concern was to identify when patients interpreted social isolation measures as invasive and to stabilize the aggressive reactions resulting from this interpretation through a psychological protocol that privileged the patient's need for self-care through the use of a mask, hygiene care and preservation of isolation, and which aimed to minimize the certainty imposed by the delusional interpretation that social isolation represented an invasion of the self. This clinical work motivated the development of a systematic review of the literature as well as some conceptual axes researched during the initial five months of the research. With the development of this research, I intend to build a protocol for the clinical treatment of psychotic patients in the context of the COVID-19 pandemic.

\section{COVID-19}

COVID-19 broke into the world in December 2019. Caused by the novel SARS-COv-2 virus, it had first been located as a regional epidemic, and first reported to the World Health Organization (WHO) on December 31, 2019. On January 30, 2020, WHO declared this new outbreak a public health emergency of international magnitude and importance-the highest level of WHO's alerts. On March 9, 2020, the Italian government announced severe emergency measures to contain the spread of the virus; soon after, on March 11, 2020, WHO declared COVID-19 as a pandemic. Since then, the world has been plagued by a new public health emergency, with the highest risk of contamination in the world. From Asia to Europe, to Africa and to North and Latin America, it took only three months for the world to succumb in a fast humanitarian emergency, given the degree of contamination of the virus and, in some cases, given the degree of severity that leads to death. Contamination occurs through contact with aerosols, and contaminated surfaces. 
The high degree of its transmission rate is worth to be emphasized: each person infected infects three other people, causing the overload of health systems until their collapse worldwide. Regarding the registration of the progress of contamination and the number of deaths, specifically in Brazil, even considering underreporting, official data indicate the growing increase in the number of cases. Thus, COVID-19 requires governments around the world to urgently develop public policies to reduce the effects of their contamination rate, as well as their most serious effects on the physical health of populations, from the beginning of infection until a possible death.

A solution for the COVID-19 pandemic in the world, through antiviral drugs and the development of vaccines, is still far away. But if, on the one hand, today, the world is still at this early stage in the field of physical health, on the other, there is a vast historical experience about the impact of humanitarian emergencies on the mental health of individuals, families and society. The current research is consistent with references from recent scientific literature on the correlation between the appearance of forms of psychological distress and the occurrence of events with a strong traumatic impact, especially regarding the functioning of the self, the regulation of affection and intersubjective relations (Briere \& Spinazzola, 2005; Schmid et al., 2013; Cloitre et al., 2014), remaining consistent with the findings of the World Health Organization, WHO (2015) and Ministério da Saúde (2020), which will be presented below.

\section{Mental Health in Humanitarian Emergencies}

Epidemics, pandemics, wars, and natural disasters make up what the World Health Organization (WHO) defined as the framework for humanitarian emergencies. We know from the historical records of World War I the relevance of the concern with the outbreak of psychological suffering. A particularly important testimony is that of Freud, in two precise moments of his reflection on World War I. In the immediate context of this outbreak, he wrote "Reflections for the Times of War and Death" (Freud, 1915b/1987), in which the author identified the change in attitude that war produced in the feeling of alienation from the world:

"This attitude was far from being direct. To anyone who listened, we were naturally prepared to maintain that death was the direct result of life and that each of us owes nature a death and must expect to pay that debt. In short, death is natural, undeniable, and inevitable. However, we were used to behaving as if it were different. We revealed an undeniable tendency to put death aside, to eliminate it from life, trying to silence it. We even have a proverb 'To think of something as if it were death', that is, as if it were our own death, naturally. In fact, it is impossible to imagine death itself, or to say the same thing in another way: in the unconscious, each of us is convinced of its immortality" (Freud, 1915b/1987: p. 85). 
The accuracy in this analysis by Freud (1915b/1987) about the impact of the War on subjectivity was remarkable, highlighting, in particular, the effect that a historical event of this magnitude had on the way human beings relate to their own finitude, what, later, Freud will call helplessness (Freud, 1926 [1925]/1987): leading the human being, from the narcissistic feeling of immortality to the imminent risk of destruction. In another moment, in "Lines of Progress of Psychoanalytic Technique", a conference held in the immediate context of the end of World War I, Freud (1919 [1918]/1987) deepens this reflection, emphasizing how the consequences of a war are as important as the losses suffered. Stressing out that the misery of the world was deepening for humanity at that time, with the increase in cases of neurosis and the emergence of the feeling of anguish, Freud (1919 [1918]/1987) had predicted, against any illusory optimism about the future, an epidemic equivalence of these forms of psychological distress to tuberculosis itself. And he was not mistaken.

Few more than a hundred years passed by and the speech by the Secretary-General of the United Nations (UN), António Guterrez, for the release of the report COVID-19 and the Need for Action on Mental Health, on May 13, 2020 does not separate himself from Freud's prediction by making it clear that, despite the COVID-19 pandemic being a physical health crisis, it produces a wide mental health crisis with the potential to worsen the world's misery:

But the COVID-19 virus is not only attacking our physical health; it is also increasing psychological suffering. Grief at the loss of loved ones, shock at the loss of jobs, isolation and restrictions on movements, difficult family dynamics, uncertainty, and fear of the future. Mental health problems, including depression and anxiety, are some of the greatest causes of misery in our world (Guterrez, 2020).

In the specific case of epidemics/pandemics, the past forty years have witnessed how humanity has lived under the pressure of viral epidemics/pandemics with a strong impact on the mental health of individuals and communities. Table 1 summarizes a historical outline of the epidemics that broke out in the world since the 1980s.

Today, WHO documents accumulate information on the impact of humanitarian emergencies on mental health, as can be seen from the "Humanitarian

Table 1. Brief history of epidemics/pandemics since the 1980s.

\begin{tabular}{cc}
\hline Epidemics/Pandemics & Year \\
\hline HIV/AIDS & $1980-1990$ \\
SARS & $2002-2003$ \\
H1N1 (Influenza pandemic) & 2009 \\
EBOLA & 2013 \\
ZIKA & 2016 \\
COVID-19 & 2019 \\
\hline
\end{tabular}


Intervention Guide (GIH-mhGAP): Clinical Management of Mental, Neurological and Substance Use Conditions in Humanitarian Emergencies" (PAHO, 2020):

1) The worsening of preexisting psychological suffering-as is the case of moderate to severe depressive disorder, psychosis and harmful use of alcohol and other drugs.

2) The triggering of other forms of suffering, directly resulting from human exposure to humanitarian emergency conditions, as is the case of acute stress, grief, and post-traumatic stress disorder.

The guide is also precise at the point where it warns to the fact that the set of pre-existing forms of psychological suffering, aggravated by emergency humanitarian situations, or triggered by them, impose a risk of self-harm and suicide. In this sense, the WHO (2015) itself has been establishing guidelines for the world population in order to reduce the anxiety of this period, also recommending the avoidance of certain coping strategies to deal with mental health situations-as is the case of use of psychoactive substances. They also corroborate the symptomatic picture already identified in the first quarter of a humanitarian emergency as presented by the Ministério da Saúde (2020)_ “Mental health and psychosocial care in the COVID-19 Pandemic: General Recommendations". The document predicts similar reactions to occur in the COVID-19 pandemic, considering the start date of the first quarter in each region:

1) Fear: of becoming ill and dying from the disease; of infecting other people; of losing loved ones; losing livelihoods and income; of being socially excluded or for being a frontline professional.

2) Feelings of: uncertainty about the future, helplessness in the face of events, helplessness, loneliness, sadness, grief, and anxiety.

3) Behavioral changes: eating (having appetite), sleeping (insomnia or excessive sleep, nightmares).

4) Interpersonal conflicts with family members and at work.

5) Changes in thinking: recurring thoughts about the pandemic, the health of loved ones, death and dying.

The data indicate how the context of humanitarian emergencies is a condition of severe and additional stress to populations, directly impacting psychosocial well-being. However, the set of records accumulated on this impact did not prevent the mental health area from being one of the most neglected by governments.

The PAHO (2018) report, "The Burden of Mental Disorders in the Region of the Americas", shows that in Latin America, the non-Latin Caribbean, South America, Canada and the United States, mental health problems are responsible for more than $1 / 3$ of the total number of disabilities. And yet, the report records how mental health financing was below what was necessary, not responding to coverage of needs in the area. Until 2018, the deficit ranged from 3 times more than current spending in high-income countries in the Americas to 435 times that in low-income countries in the region (PAHO, 2018). This explains the 
UN's concern to raise awareness among countries to reverse neglect and low investment in mental health services in favor of expanding psychosocial coverage for individuals, families and communities that have been affected by the impacts of uncertainty regarding the development of treatments and cure for COVID-19, uncertainty about the future, isolation and loss of loved ones that could not be elaborated through the collective ritual of mourning and funeral.

In the context of a pandemic of the magnitude of COVID-19-in which social isolation and, more radically the lockdown, are the main directions of prevention and treatment for the virus, and that uncertainty about the future is consolidated as a horizon in a scenario still without precise medicines-it is crucial to deepen the research on psychological suffering.

The study by Lai et al. (2020) records in the Republic of China high rates of occurrence of depression (50\%), anxiety (45\%) and insomnia (34\%) in health professionals. This is also true about the general population. The UN (2020) cites two recent studies in Ethiopia and Canada. The data from the Ambaw survey, mentioned by the UN, referring to the population of the state of Amhara, Ethiopia, estimated a percentage of $33 \%$ of consistent symptoms for depressive disorder in the context of the COVID-19 pandemic, representing a 3-fold increase in comparison with Ethiopia's estimates before the pandemic. These estimates take on an additional severity when the authors found that, to deal with the stressor of the pandemic, individuals appeal to the use of psychoactive substances, or develop addictive behaviors related to the internet. Canada's statistic on alcohol consumption shows that $20 \%$ of the population aged 15 to 49 years increased consumption during the COVID-19 pandemic.

The study by Thackur \& Jain (2020) is particularly significant and deserves to be highlighted for presenting a sample of case study references, in the year in which the impact of social isolation, the economic crisis and the stress and anxiety experienced by professionals stand out of health as predictive factors for triggering depression and suicide in the context of the COVID-19 pandemic.

Today, even after six months of the outbreak in Wuhan, we do not have a vast scientific literature on the precise extent of its impact on mental health. However, it is worth highlighting the expressions used by its residents when calling the situation of the pandemic: "end of the world" (Lima et al., 2020).

The use of these expressions shows how the language tries to circumscribe the traumatic dimension of a humanitarian emergency of the magnitude of the COVID-19 pandemic, and its effects on psychic functioning: end of the world and panic. Certainly, over the next few years, scientific production in the humanities and health technologies will bear witness to these impacts.

\section{Etiology of Psychosis and Function of Delusion in Freud}

The article presented some references that support the correlation between the emergence of forms of psychological distress and the occurrence of events with a strong traumatic impact, especially with regard to the functioning of the self, the 
regulation of affection and intersubjective relationships (Briere \& Spinazzola, 2005; Schmid et al., 2013; Cloitre et al., 2014), remaining consistent with the findings of the World Health Organization (2015) and Ministério da Saúde (2020) for humanitarian emergencies.

Regarding psychoanalysis, the classic reading conducted by Freud (1911/1987), in "Psychoanalytical Notes on an autobiographical account of a case of paranoia (Dementia paranoides)", is still central to research on the psychic etiology of psychosis. The contact with the rich content of "Memoirs of a Nerve Sick" (1903/1984), written by Daniel Paul Schreber, gave Freud the necessary clinical material to verify the hypothesis of the occurrence of drive invasion in the etiology of psychosis, such as psychic work of repair, of attempted cure, through the delusion of transformation into a woman: "The delusional formation, which we assume to be the pathological product, is, in reality, an attempt to reestablish itself, a process of reconstruction" (Freud, 1911/1987: pp. 94-95).

This formulation was evaluated by the author himself as something that was never conceived in these terms before him and, in particular, before the elaboration of the concept of drive and the possibility of interrogating himself in the light of this concept about the etiology of the onset of psychosis (Freud, 1911/1987). In fact, in "Psychoanalytical Notes on an autobiographical account of a case of paranoia (Dementia paranoides)", Freud (1911/1987) will start from the uniqueness of Daniel Paul Schreber's clinical picture to, anchored in the theoretical framework of the first drive theory, support the hypothesis of a mixed picture of psychosis-defined by him as dementia paranoids-and to investigate its psychic etiology.

Freud's (1911/1987) hypothesis was, then, elaborated to elucidate the etiology of the experience of the collapse of the world in schizophrenia. It is about the rejection of an intolerable idea for the Self and its projection for reality, so that “(...) what was internally abolished returns from without” (Freud, 1911/1987: p. 95). This hypothesis made it possible to isolate the process at play in triggering psychosis-rejection (Verwerfung) - and its effects on psychic functioning:

1) The retraction of the drive, previously invested in other people.

2) Your fixation on the self.

3) The outbreak of the delusion of persecution.

4) The occurrence of the delusion of greatness associated with the delusion of persecution.

In advancing towards elaborating a theory about the constitution of the self, in “About Narcissism: An Introduction”, Freud (1914/1982) re-asks the question regarding the fate of the drive, in schizophrenia and characterizes it in two stages:

Time 1: Retraction of drive investment in relation to objects in the direction of the self, without substitution for fantasy (according to effects 1 and 2).

Time 2: Return to the logic of autoeroticism with the onset of hypochondriac phenomena-triggering of psychotic symptoms (which would indicate, not the outbreak of the delusion, but the very failure in the constitution of the self). 
In this sense, re-reading the theories about the Schreber case, conducted by Freud (1911/1987), in the light of the theoretical advance of "About Narcissism: An Introduction (1914/1987)", the work of restoring the drive investment in objects by means of formation of delusion is secondary, characterized as delusion of greatness (megalomania) and delusion of persecution, and constituting attempts to drive the drive back to investment in objects.

Regarding to the text "The Unconscious", Freud (1915a/1987) re-emphasizes the specific destiny assumed by the drive in the repression process in schizophrenia and makes a distinction regarding hysteria. In Appendix $\mathrm{C}$ of the text, Freud (1915a/1987) distinguishes the representational field in the unconscious and in the preconscious-conscious system, placing the representation-of-thing in the unconscious and the representation-of-word and the representation-of-thing in the pre-conscious-conscious system. The location of the thing representation in the unconscious indicates that the object investment obeys the logic of the unconscious. And it is from this conceptual framework that Freud (1915a/1987) elucidates the specificity of the defense process in psychoses and, especially, in the clinical form of schizophrenia: in it occurs the retraction of the drive investment of representations-of-thing and the advance about word-representations. Here, the emphasis is on the clinical effect of this retraction in the field of verbal expression, which undergoes a disorganization to the point of becoming totally incomprehensible. Taking as a reference a case attended by Victor Tausk, Freud (1915a/1987) identifies in his logic the same working structure of the hypochondriac phenomena resulting from the retraction of the drive for autoeroticism: "Thus the schizophrenic oral manifestation exhibits a hypochondriac characteristic: it became if it "speaks of the organ" (Freud, 1915a/1987: p. 226).

The hypotheses of the rejection of the psychic representation and the retraction of the drive, formulated by Freud within the framework of the first drive theory, are not abandoned. But they will be thought in the light of the death drive theory from 1920 on. The crucial references for the understanding of the advance of a theorization about the specific psychic processes of psychosis are the texts "Neurosis and psychosis" (Freud, 1924a/1987) and "The loss reality in neurosis and psychosis" (Freud, 1924b/1987).

In both references, Freud (1924a/1987, 1924b/1987) argues that neurosis and psychosis translate the failure of the self to reconcile the drive imperative (death drive) and the demands of civilization. From this common failure, the author will define, in Neurosis and psychosis (Freud, 1924a/1987), the specificity of psychic processes in neurosis and psychosis: in neurosis, the conflict between the instinctual imperative (death drive) and the civilization's demands appears in the form of an impasse between the id and the self; in psychosis, the conflict appears in the form of an impasse between the self and the outside world. Both psychic processes produce, in a second time, the loss of reality, and the difference lies in the solution: in neurosis, the solution to the loss of reality lies in the investment in fantasy; in psychosis, it lies in delirium. This is defined as resulting 
from the process of replacing the rejected reality, fulfilling the function of patching the loss of reality. From the set of references above, the conceptual axes that support Freud's theory on psychosis are extracted. They are:

1) The psychic process that constitutes psychosis: “(...) what has been abolished internally returns from without” (Freud, 1911/1987: p. 95).

2) The relevance of determining trigger conditions.

3) The hypothesis of the loss of reality because of the constitution of psychosis and the reparative function of delusion (Freud, 1911/1987).

4) The irruption of the logic of hypochondriac phenomena in verbal expression, evidencing their subjection to the pulsional invasion (Freud, 1915a/1987).

5) The recognition of the hegemony of drive functioning in the etiology of loss of reality, evidenced in neurosis and psychosis, and the specificity of the function of delusion in psychosis in relation to the formation of fantasy in neurosis (Freud, 1924a/1987, 1924b/1987).

This brief overview of Freud's formulation on the etiology of psychosis-in which delusion is a repairing construction of the most dramatic effects of rejection (verwerfung) on the distribution of the drive between self and objects-is the conceptual basis from which it is necessary to consider the incidence of traumatic events, of the magnitude of the COVID-19 pandemic, in life. In this sense, the pandemic places the researcher in front of the problem of the status of language in psychosis, further complexifying the etiological research of the alterations of the self, typical of psychosis. Considering the exposure to the dangers imposed by the virus, the reduced possibilities to participate in society because of social avoidance measures (from isolation to lockdown), uncertainty about the future, we question whether the worsening of this pre-existing psychopathology to COVID-19, as observed by documents from WHO (2015) and SAMHSA (2019), is due precisely because the social changes imposed exacerbate these typical elements of functioning psychosis (experience of language in the raw state operating directly on the patient's body, bodily dissolution).

\section{The Psychopathology of the Self in Psychosis}

The specialized literature in psychopathology (Maleval, 1996; Álvarez, Estéban, \& Sauvagnat, 2004; Dalgalarrondo, 2019; Maleval, 2019) illustrates a vast field of these changes. Maleval $(1996,2019)$, specialized in the etiological research of cases of unchained psychosis-and anchored in Freud's references about the impact of the rejection process (Verwerfung) on the constitution of the self and on the Lacanian model of the mirror stadium to explain it constitution of the self-lists two fundamental disturbances in the relationship between the image and the self in psychosis, even when they are not yet triggered, contributing to the earlier recognition of the occurrence of elementary phenomena, in these cases, and consequently to greater precision in the direction of treatment. Table 2 summarizes such disturbances. 
Álvarez, Estéban, \& Sauvagnat (2004) locates these disorders listed by Maleval $(1996,2019)$ within the framework of spatio-temporal disorientation, seen in psychosis, under the classification of autopsychic orientation disorders (psychic self and body self). Table 3 illustrates the classification proposed by Álvarez, Estéban, \& Sauvagnat (2004).

Table 2. Disorders in the relationship between the image and the self, verified in unchained psychoses.

Disturbances of Features
the imaginary

the imaginary

Personality "as if" 1 . Normality: the as if personality guarantees the patient the appearance of a stable life, as if he had a complete and sensitive emotional capacity for this. They are intellectually preserved. But, in fact, they follow a protocol without originality. The same occurs with affective relationships: affective expressions are formal and devoid of any more intimate experience.

2. Suggestibility: The person has a passive readiness to be influenced and an identification of an automaton type.

3. Presence of aggressive tendencies on the basis of passive readiness.

Mirror sign The patient shows exacerbated concern with his image, examining himself long and often before reflecting surfaces. The patient has the experience of being side by side with the image and, suddenly, he may be filled with horror at something terrible on the surface of the mirror (himself). Detected in classical melancholic states and schizophrenia, but it is not uncommon in cases of ordinary psychosis. It has 2 stages:

1. Unceasing observation: The person experiences the enigmatic character of the image. He feels that a change has occurred, but he cannot account for what is unusual or abnormal. In this sense, incessant observation is a response to the more or less restless strangeness that the person experiences regarding the change that he identifies.

2. Autoscopy: the patient experiences the absence of half of his body, experiencing that someone like him takes his place.

Table 3. Autopsychic orientation disorders.

\begin{tabular}{ll}
\hline Autopychic Orientation Disorder & Clinical Forms \\
\hline Psychic Ego & Depersonalization: \\
& 1. Influence device. \\
& 2. Disorporation. \\
& 3. Dealization. \\
& 4. Personality as if. \\
Body ego & Anognosia \\
& Asomatognosia \\
& Autoscopy \\
Deuteroscopy & Prosopoagnosia \\
& Dysmorphophobia. \\
\end{tabular}


Dalgalarrondo (2019), in turn, establishes the amplitude of these disorders in the relationship between the image and the self, ordering them into changes in the psychic self, the body self, the social self and the total self. As shown in Table 4 , the spectrum of these changes is large, demonstrating the wide range both from the notion of self to psychopathology-beyond the nuclearity of the self-and from the effects of its alteration on psychosis.

The references mentioned here show the broad picture of clinical phenomena typical of the self-disorders, of the relationship between the self and the image, in psychosis. Its etiology was investigated by Lacan (1932/1987), in the framework of the study of the case Aimèe (Margueritte Anzieu) - a case of paranoia with passage to the act. Margueritte's paranoia had as a distinctive feature the specular unfolding and the formation of the double involving the French actress Huguette Duflos, until putting pressure on Margueritte's psychic functioning in the attempted murder of the actress.

The case in question was fundamental for the elaboration of the mirror stage theory to elucidate the psychic etiology of the triggering of psychosis and of what Lacan (1932/1987) himself called self-punishment paranoia. Advancing in the clinical research initiated at the time of the study of the Aimèe case, Lacan elaborated

Table 4. Clinical spectrum of self-disorders in psychosis

\begin{tabular}{|c|c|}
\hline \multirow[t]{4}{*}{ Psychic Self } & 1. Feeling of diminishing basic self. \\
\hline & 2. Perceptual distortion of first person: \\
\hline & $\begin{array}{l}\text { 2.1. Disorders of initiative or intentionality of thought, impulses, feelings, } \\
\text { imaginations. }\end{array}$ \\
\hline & 2.2. Loss of awareness of the continuity of the action itself. \\
\hline \multirow[t]{9}{*}{ Body Self } & 1. Morphological changes. \\
\hline & 2. Phenomena related to the mirror image. \\
\hline & 3. Strangeness of the body self. \\
\hline & 4. Disintegration of the body self. \\
\hline & 5. Spatialization and anomaly of bodily experiences. \\
\hline & 6. Cenesthesic experiences of the body self. \\
\hline & 7. Motor changes of the body self. \\
\hline & 8. mimetic handling experiences. \\
\hline & 9. Threatening feelings due to body contact. \\
\hline \multirow[t]{4}{*}{ Social Self } & 1. Confusion with each other. \\
\hline & 2. Radical confusion of identity. \\
\hline & 3. Feeling of change in relation to chronological age. \\
\hline & 4. Feeling of change in relation to gender. \\
\hline \multirow[t]{6}{*}{ Total Self } & 1. Decreased sense of presence. \\
\hline & 2. Radical feeling of centrality. \\
\hline & 3. Hyper-reflexivity. \\
\hline & 4. Radical split of the self. \\
\hline & 5. Transitivism. \\
\hline & 6. Feeling of total annihilation, of disappearance. \\
\hline
\end{tabular}


the mirror stage as a maker of the function of the self as revealed to us in the analytical experience (1949/1998), the theory about the formation of the self defining its constitution by identifying an imago that does not correspond to the condition of initial body fragmentation that affects all human beings in the initial stage of life. Situated in a concrete period of child development (between 6 and 18 months), the mirror stage formalizes how fragmentation finds in the external image, a fundamental alienation that will enable the creation of a gestalt. This fundamental alienation in the external image depends on a word of recognition, a symbolic message, which comes from the other towards the fragmented body, and verified by Lacan (1949/1998) in the child's movement towards the adult's look or words that supports it.

The constitution of the self includes an alterity, which is beyond the child, and which places for them and through language, the place from which they must identify themself with the image. In this sense, language plays a crucial role in the organization of the fragmented body: it promotes a narcissistic armor that unifies the body in an image. These findings by Lacan (1949/1998) provide a precise indication of the etiology of the alterations of the self in psychosis until its more radical regression to the fragmented body, as seen in schizophrenia: the fragility, the decline in the operability of this symbolic message that results in the pictures of body fragmentation and dissolution. Maleval (1996) reproduces Ostancow's example about a 21-year-old patient who suffered from autoscopy:

Over the course of several years, he devoted himself to a thorough examination of his figure, spending entire hours in front of a mirror. (...) He believed, he said, to observe that the people around him noticed that he had a comical aspect, a tiny head, a narrow forehead, the whole structure of a chicken. He claimed to have heard it said about him that he had no nose, and when he returned to his home he looked at himself in the mirror and, in fact, it seemed to him that his nose had changed shape and that his forehead had become very narrow (Maleval, 1996: p. 633)

The clinical description above highlights the elements present in the onset of psychosis: the autonomy of language in its raw state, divorced from its status of message, meaning and directed to the patient's body, the disintegration of the body unit following the typical regression until the body fragmentation at the mirror stage.

The systematic review carried out in the initial five months of the survey allows us to consider that these elements in the light of the situation of the pandemic of COVID-19-with the exposure to the dangerousness imposed by the virus, the reduction of the possibilities of participating in society because of the social avoidance measures (from isolation to lockdown), uncertainty about the future-contribute to the worsening of cases of pre-existing psychosis to COVID-19. The continuity of the research will aim to verify, through clinical studies resulting from the virtual psychological care clinic project, the hypothesis that the pandemic situation exacerbates these typical elements of the functioning 
of psychosis (experience of raw language operating directly on the patient's body, bodily dissolution).

The set of references raised by the systematic review of the specialized literature on the topic, shows the place that psychoanalytic psychopathology has in contributing to the advancement of research in diagnosis and therapeutics of the psychopathologies of the self in psychosis, considering the humanitarian emergency situation.

\section{Conclusion}

According to the literature review carried out in the five months of development of the research project "Psychoanalytic Investigation of Clinical Phenomena linked to Psychosis, in the Pandemic Context of COVID-19", exposure to the dangerousness of the virus, reducing the possibilities of participating in the society because of social avoidance measures and uncertainty about the future are factors that aggravate psychosis cases. This means that the COVID-19 outbreak did not reveal a pre-existing psychopathology. My research indicates that the COVID-19 outbreak has a serious impact on the language experience experienced by psychotic patients, aggravating psychopathological phenomena such as bodily dissolution.

At the current stage of knowledge at COVID-19, psychopathological science does not yet have all the discoveries in the field of mental health. But the impact of the pandemic on mental health is an important challenge for every researcher in the field. And I hope that this challenge produces important knowledge that contributes to the development of mental health policies. The continuity of my research hopes, through the advancement of clinical studies, to contribute to the development of a specific protocol for approaching and treating psychotic patients in a humanitarian emergency. And, thus, adding to the knowledge about the etiology, prevention, and treatment of the most severe cases of psychosis.

\section{Conflicts of Interest}

The author declares no conflicts of interest regarding the publication of this paper.

\section{References}

Álvarez, J. M., Estéban, R., \& Sauvagnat, F. (2004). Tratado de psicopatologia psicoanalítica. Madri: Sintesis.

Briere, J., \& Spinazzola, J. (2005). Phenomenology and Psychological Assessment of Complex Posttraumatic States. Journal of Traumatic Stress, 18, 401-412. https://doi.org/10.1002/jts.20048

Cloitre, M. et al. (2014). Distinguishing PTSD, Complex PTSD, and Borderline Personality Disorder: A Latent Class Analysis. European Journal of Psychotraumatology, 5, 25097. https://doi.org/10.3402/ejpt.v5.25097

Dalgalarrondo, P. (2019). Psicopatologia e semiologia dos transtornos mentais. Porto Alegre: Artmed. 
Freud, S. (1911). Notas psicanalíticas sobre um relato autobiográfico de um caso de paranoia [dementia paranoides]. In O Caso Schreber, Artigos sobre Técnica e Outros Trabalhos (Edição Standard Brasileira das Obras Completas de Sigmund Freud, 12) (pp. 15-108). Rio de janeiro: Editora Imago.

Freud, S. (1914). Sobre o Narcisismo: Uma Introdução. In A História do Movimento Psicanalítico, Artigos sobre a Metapsicologia e Outros Trabalhos (Edição Standard Brasileira das Obras Completas de Sigmund Freud, 14) (pp. 83-119). Rio de janeiro: Editora Imago.

Freud, S. (1915a). O Inconsciente. In A História do Movimento Psicanalítico, Artigos sobre a Metapsicologia e Outros Trabalhos (Edição Standard Brasileira das Obras Completas de Sigmund Freud, 14) (pp. 13-74). Rio de janeiro: Editora Imago.

Freud, S. (1915b). Reflexões sobre os Tempos de Guerra e Morte. In A História do Movimento Psicanalítico, Artigos sobre a Metapsicologia e Outros Trabalhos (Edição Standard Brasileira das Obras Completas de Sigmund Freud, 14) (pp. 310-341). Rio de janeiro: Editora Imago.

Freud, S. (1919 [1918]). Linhas de Progresso da Técnica Psicanalítica. In Uma Neurose Infantil e Outros Trabalhos (Edição Standard Brasileira das Obras Completas de Sigmund Freud, 17) (pp. 169-182). Rio de janeiro: Editora Imago.

Freud, S. (1924a). Neurose e Psicose. In O Ego e O Id e Outros Trabalhos (Edição Standard Brasileira das Obras Completas de Sigmund Freud, 19) (pp. 167-171). Rio de janeiro: Editora Imago.

Freud, S. (1924b). A Perda da Realidade na Neurose e na Psicose. In O Ego e O Id e Outros Trabalhos (Edição Standard Brasileira das Obras Completas de Sigmund Freud, 19) (pp. 205-209). Rio de janeiro: Editora Imago.

Freud, S. (1926 [1925]). Inibição, Sintoma e Angústia. In Um estudo Autobiográfico, Inibições, Sintoma e Ansiedade, Análise Leiga e Outros Trabalhos (Edição Standard Brasileira das Obras Completas de Sigmund Freud, 20) (pp. 93-201). Rio de janeiro: Editora Imago.

Guterrez, A. (2020). Mental Health Services Are Essential Part of All Governments Responses to COVID_19, May 2020.

https://www.un.org/en/coronavirus/mental-health-services-are-essential-part-all-gover nment-responses-covid-19

Hao, F., Tan, W., Jiang, L., Zhang, L., Zhao, X. et al. (2020). Do Psychiatric Patients Experience More Psychiatric Symptoms during COVID-19 Pandemic and Lockdown? A Case-Control Study with Service and Research Implications for Immunopsychiatry. Brain, Behaviour and Immunity, 87, 100-106. https://doi.org/10.1016/j.bbi.2020.04.069

Lacan, J. (1932). Da psicose paranóica em suas relaçóes com a personalidade. Rio de Janeiro: Forense Universitária, 1987.

Lacan, J. (1949). O estágio do espelho como formador da função do eu tal como nos é revelada na experiência analítica. In J. Lacan (Ed.), Escritos (pp. 96-103). Rio de Janeiro: Jorge Zahar, 1998.

Lai, J. et al. (2020). Factors Associated with Mental Health Outcomes among Health Care Workers Exposed to Coronavirus Disease 2019. JAMA Network Open, 3, e203976. https://doi.org/10.1001/jamanetworkopen.2020.3976

Lima, T. et al. (2020). The Emotional Impact of Coronavirus 2019-nCoV (New Coronavirus Disease). Psychiatry Research, 287, Article ID: 112915. https://doi.org/10.1016/j.psychres.2020.112915

Maleval, J. C. (1996). Identificaciiones Imaginarias y Estructura Psicótica no desencadenada. Revista de la Associación Española de Neuropsiquiatria, 16, 629-646. 
Maleval, J. C. (2019). Repères pour la Psychose Ordinaire. Paris: Navarin Editeur.

Ministério da Saúde (2020). Saúde mental e Atenção psicossocial na Pandemia COVID-19: Recomendações Gerais. Brasília: FIOCRUZ.

PAHO. Organização Panamericana de Saúde. Organização Mundial da Saúde. (2020). Guia de Intervenção Humanitária (GIH-mhGAP): Manejo Clínico de Condições Mentais, Neurológicas e por Uso de Substâncias em Emergências Humanitárias. OPAS.

http://www.paho.org

PAHO. Organización Panamericana de la Salud. Organización Mundial de la Salud. (2018). La carga de los trastornos mentales en la Región de las Américas. Washington DC. http://www.paho.org

SAMHSA (2019). Disasters and People with Serious Mental Illness.

Schmid et al. (2013). Developmental Trauma Disorder: Pros and Cons of Including Formal Criteria in the Psychiatric Diagnostic Systems. BMC Psychiatry, 13, 3. https://doi.org/10.1186/1471-244X-13-3

Thackur, V., \& Jain, A. (2020). COVID 2019-Suicides: A Global Psychological Pandemic. Brain, Behavior, and Immunity, 88, 952-953. https://doi.org/10.1016/j.bbi.2020.04.062

United Nations, UN. (2020). Policy Brief: COVID-19 and the Need for Action on Mental Health.

https://www.un.org/sites/un2.un.org/files/un_policy_brief-covid_and_mental_health_f inal.pdf

WHO. Organização Mundial Da Saúde (2015). Guia de Intervenção Humanitária (GIH-mhGAP): Manejo Clínico de Condições Mentais, Neurológicas e por Uso de Substâncias em Emergências Humanitárias. Organização Mundial da Saúde.

Zhang, J., Wu, W., Zhao, Z., \& Zhang, W. (2020). Recommended Psychological Crisis Intervention Response to the 2019 Novel Coronavirus Pneumonia Outbreak in China: A Model of West China Hospital. Precision Clinical Medicine, 3, 3-8.

https://doi.org/10.1093/pcmedi/pbaa006 